\title{
FORMULASI DAN UJI STABILITAS KRIME KSTRAK METHANOL DAUN BELUNTAS (Pluchea indica L.) DARI KOTA BENTENG KABUPATEN KEPULAUAN SELAYAR PROVINSI SULAWESI SELATAN
}

\author{
*)Alfreds Roosevelt, *)Sulfiyana H Ambo Lau, *)Hazhima Syawal \\ *)Akademi Farmasi Sandi Karsa Makassar \\ *)Program Studi D-III Farmasi Sandi Karsa Makassar
}

\begin{abstract}
ABSTRAK
Telah dilakukan penelitian mengenai Formulasi Dan Uji Stabilitas Krim Ekstrak Metanol Daun Beluntas (Pluchea indica L.) Dari Kota Benteng Kabupaten Kepulauan Selayar Provinsi Sulawesi Selatan dengan tujuan mengetahui apakah daun Beluntas (Pluchea indica L.) dari kota Benteng Kabupaten Kepulauan Selayar Provinsi Sulawesi Selatan Memiliki Kandungan Kimia yang sama dengan daerah lain dan membuat formulasi krim untuk mengetahui apakah membentuk formulasi krim dengan Stabilitas yang baik, menggunakan perbandingan asam stearat 5\%,10\% dan 15\%. Penelitian ini adalah penelitian eksperimen. Dengan melakukan Uji Identifikasi yaitu Alkaloid, Flavonoid, Tanin, Saponin dan steroid, Formulasi krim ekstrak daun Beluntas (Pluchea indica L.) dan uji stabilitas kirm daun Beluntas (Pluchea indica L.) yang meliputi uji organoleptis, uji homogenitas, pengukuran $\mathrm{pH}$, uji daya sebar, uji daya lekat dan cycling test. Adapun hasil dari penelitian dengan menggunakan metode kualitatif dengan beberapa pengujian diperoleh yaitu Alkaloid negatif (-), Flavonoid positif (+), Tanin positif (+), Steroid/Terpenoid positif (+), Saponin positif (+). Hasil penelitian Pada uji stabilitas krim organoleptis ketiga formula memiliki warna hijau, aroma khas dari zat aktif. Pada uji homogenitas, ketiga sediaan krim menunjukkan susunan homogen yang baik. Pada pengukuran $\mathrm{pH}$, ketiga formula krim memenuhi persyaratan $\mathrm{pH}$ yaitu antara 4-7. Pada pengujian daya sebar, ketiga formula krim memenuhi persyaratan, yaitu antara 5-7. Pada uji daya lekat, ketiga formula krim memenuhi persyaratan, yaitu antara 2-300 detik. Pada cycling test, ketiga formula krim tidak menunjukkan pemisahan fase.
\end{abstract}

Kata kunci : Identifikasi, Daun Beluntas (Pluchea indica L.), metode kualitatif, Formulasikrim, Uji Stabilitas

\section{PENDAHULUAN}

\section{A. Latar Belakang}

Penggunaan bahan-bahan alam sebagai obat bukan merupakan yang baru lagi, melainkan sudah menjadi budaya dan digunakan secara turun temurun.Hal ini sangat menguntungkan bagi masyarakat Indonesia karena bahan bakunya mudah didapat, relatif murah dan dapat diramu sendiri di rumah(Agoes, 2010).

Berbagai tanaman obat dan ribuan tanaman berpotensi obat di Indonesia mengandung beraneka ragam jenis senyawa kimia alami.Berdasarkan penggunaan tradisional dan berbagai penelitian ilmiah, tanaman tersebut memiliki berbagai efek farmakologis dan bioaktivitas penting mulai dari potensi sebagai anti penyakit sampai penyakit degenarit. Disisi lain pengobatan dengan senyawa tunggal atau senyawa isolat murni maupun sintesis belum memberikan kesembuhan optimal dan paripurna. Maka masyarakat berupaya untuk mencari obat alternatif, terutama dari herbal(Azis Saifuddin, 2011).

Daun Beluntas (Pluchea indica L.) biasa digunakan di daerah Selayar sebagai tanaman pagar dan sebagai obat bau badan yang tidak sedap dan Daun Beluntas (Pluchea indica L.) menurut literatur sebelumnya berkhasiat untuk meingkatkan nafsu makan (stomatik), penurun demam (antipiretik), peluruh keringat (diaforetika), penyegar, antibakteri, TBC kelenjar, nyeri pada rematik dan keputihan. Daun Beluntas (Pluchea indica L.) mengandung alkaloid, flavonoid, tannin, minyak atsiri, natrium, kalium, aluminium, kalsium, magnesium, dan fosfor (Dalimartha, 1999).

Skrining fitokimia merupakan tahap pendahuluan dalam suatu penelitian fitokimia yang bertujuan memberi gambaran tentang golongan senyawa yang terkandung dalam tanaman yang diteliti (Eva Susanty Simaremare, 2014).

Krim merupakan salah satu sediaan setengah padat yang dimaksudkan untuk pemakaian luar yang pemakaiannya dengan cara dioleskan pada bagian kulit. Uji stabilitas atau pengujian pada sediaan krim biasanya dilakukan dengan beberapa cara seperti organoleptik, homogenitas, pengujian $\mathrm{pH}$, pengujian daya lekat, pengujian daya sebar dan cycling test.

Alasan peneliti ingin mengidentifikasi dan memformulasi Daun Beluntas (Pluchea indica L.) karena peneliti ingin membandingkan kandungan senyawa kimia yang ada didalam daun Beluntas (Pluchea indica L.) yang peneliti dapatkanpada jurnal dengan daun Beluntas (Pluchea indica L.) yang ada di Kota Benteng Kabupaten Kepulauan Selayar Provinsi Sulawesi Selatan dan apakah daun 
Beluntas (Pluchea indica L.) di daerah tersebut stabil dibuat dalam bentuk sediaan berupa krim.

Upaya untuk memberikan nilai tambah dari tanaman ini yaitu perlu dilakukan penelitian terhadap kandungan kimia serta khasiatnya. Penelitian berupa pengujian fitokimia dan formulasi stabil.

Oleh karena itu peneliti merasa tertarik untuk melakukan penelitian identifikasi senyawa kimia dan membuat formulasi stabil daun Beruntas (Pluchea indica L.).

\section{B. Rumusan Masalah}

Apakah Daun Beluntas (Pluchea indica L.) dari kota Benteng Kabupaten Kepulauan Selayar Provinsi Sulawesi Selatan memiliki kandungan kimia yang sama dengan yang telah diteliti di daerah lain dan stabil dibuat sediaan krim ?

\section{Tujuan Penelitian}

1. Mendapatkan hasil kandungan senyawa kimia dari daun Beluntas (Pluchea indica L.) dari kota Benteng Kabupaten Kepulauan Selayar Provinsi Sulawesi Selatan

2. Membuat formulasi stabil Ekstrak daun Beluntas (Pluchea indica L.) dari kota Benteng Kabupaten Kepulauan Selayar Provinsi Sulawesi Selatan

3. Uji stabilitas ekstra daun Beluntas (Pluchea indica L.) dari kota Benteng Kabupaten Kepulauan Selayar Provinsi Sulawesi Selatan.

\section{Manfaat Penelitian}

1. Memberikan data ilmiah tentang kandungan senyawa kimia dan formulasi stabil daun Beluntas (Pluchea indica L.) dari Kota Benteng Kabupaten Kepuluan Selayar Provinsi Sulawesi Selatan.

2. Menambah bahan referensi tentang senyawa kimia yang terdapat dalam daun Beluntas (Pluchea indica L.) dan formulasi stabil dari Beluntas (Pluchea indica L.) dalam sediaan krim.

\section{METODE PENELITIAN}

\section{A. Jenis Penelitian}

Jenis penelitian ini yaitu penelitian eksperimen untuk menunjukkan identifikasi senyawa kimiadan formulasi stabil dalam sediaan krim dari daun beluntas (Pluchea indica L.) dari Kota Benteng Kabupaten Kepuluan Selayar.

\section{B. Waktu Dan Tempat Penelitian}

Penelitian ini dilakukan pada bulan Maret 2019 di Laboratorium Fitokimia Akademi Farmasi Sandi Karsa Makassar.

\section{Alat Dan Bahan}

Alat-alat yang digunakan antara lainalat maserasi, anak timbangan 10 gram, batang pengaduk, cawan porselin, corong, gelas ukur 10 $\mathrm{ml}$ (pyrex), gelas kimia $500 \mathrm{ml}$ (pyrex), gelas arloji, kain kasa, kompor gas, kertas perkamen, $\mathrm{pH}$ universal, lumpang dan stamfer, objek glass, pipet tetes, penangas air, rotary evaporator (Gucci), sendok tanduk, termometer, dan timbangan analitik.

Bahan-bahan yang digunakan yaitu Aquadest $\left(\mathrm{H}_{2} \mathrm{O}\right)$, Amil Alkohol,Asam Sulfat $\left(\mathrm{H}_{2} \mathrm{SO}_{4}\right)$, Asam stearate, Asam Klorida ( $\mathrm{HCl})$, Besi(III) Klorida $\left(\mathrm{FeCl}_{3}\right)$,Gliserin,Kertas saring, Lakban, Metanol $\left(\mathrm{CH}_{4} \mathrm{O}\right)$, Minyak Zaitun, N-Heksan, Natrium Hidroksida $(\mathrm{NaOH})$, Natrium Klorida ( $\mathrm{NaCl}$,Nipagin, Nipasol, Parafin Liquidum, Pereaksi Liberman-bouchardat, Pereaksi Mayer,Pereaksi Dragendrof, dan Pereaksi Bouchardat, Serbuk Mg, Sampel Ekstrak daun Beluntas (Pluchea indica L.), Trietanolamin.

\section{Metode Kerja}

1. Pengambilan Sampel

Sampel dikumpulkan di Kota Benteng Kabupaten Kepulauan Selayar Provinsi Sulawesi Selatan.

\section{Pengolahan Sampel}

Daun Beluntas (Pluchea indica L.)yang telah dikumpulkan, dibersihkan dengan cara dicuci denga air yang mengalir lalu dipotong-potong kecil kemudian dikeringkan dengan cara diangin-anginkan, setelah kering sebagian diserbukkan lalu dilakukan proses ekstraksi, kemudian di lakukan uji identifikasi kimia dan uji formulasi stabil sediaan krim.

3. Pembuatan Ekstrak

Ekstraksi daun Beluntas (Pluchea indica L.) yaitu dengan menggunakan metode maserasi di mana alat terlebih dahulu dicuci, dibersihkan dan dikeringkan. Simplisia yang telah dipotong-potong kecil sesuai dengan derajat kehalusannya kemudian ditimbang. Setelah itu, dimasukkan ke dalam wadah maserasikemudian ditambahkan dengan methanol bersamaan dengan simplisia. Setelah wadah maserasisudah terisi dengan cairan penyari dan simplisia, wadah maserasi ditutup rapat lalu dibiarkan sampai kurun waktu 5 hari dan diaduk 1x24 jam, pelarut diganti tiap 5 hari sekali dan penggantian pelarut dilakukan sebanyak 3 kali. Filtrat dan endapan dipisahkan, selanjutnya filtrat diuapkan pada rotavapor dan diidentifikasi.

4. Pembuatan Pereaksi

a. Larutan pereaksi Dragendrof

Sebanyak 8 gram Bismuth Nitrat dilarutkan dalam Asam Nitrat $20 \mathrm{ml}$ 
kemudian dicampur dengan larutan Kalium Iodida sebanyak 27,2 gram dalam $50 \mathrm{ml}$ Air suling. Campuran didiamkan sampai memisah sempurna. Larutan jernih diambil dan diencerkan dengan air secukupnya hingga $100 \mathrm{ml}$.

b. Larutan pereaksi Bouchardat

Sebanyak 4 gramKalium Iodida dilarutkan dalam $20 \mathrm{ml}$ Air suling kemudian ditambah 2 gram Iodium sambil diaduk sampai larut, lalu ditambah Air suling hingga $100 \mathrm{ml}$.

c. Pereaksi Mayer

Sebanyak 5 gram Kalium Iodida dalam $10 \mathrm{ml}$ Air suling kemudian ditambahkan larutan 1,36 gram Merkuri(III) Klorida dalam $60 \mathrm{ml}$ Air suling. Larutan dikocok dan ditambahkan Air suling hingga 100 $\mathrm{ml}$.

d. Larutan pereaksi Liebarman-Bourchard 20 tetes Asam Asetat Anhidrat dan 1 tetes Asam Sulfat pekat.

5. Identifikasi Senyawa Kimia

a. Pemeriksaan alkaloid

Sebanyak 0,5 gram serbuk simplisia ditimbang, ditambahkan $1 \mathrm{ml}$ Asam Klorida $2 \mathrm{~N}$ dan $9 \mathrm{ml}$ Air suling, dipanaskan diatas tangas air selama 2 menit, didinginkan lalu disaring, filtrat dipakai untuk untuk uji alkaloid. Diambil 3 tabung reaksi, lalu kedalam masingmasing tabung reaksi dimasukan $0,5 \mathrm{ml}$ filtrat.

1) Pada tabunng 1, ditambahkan 2 tetes pereaksi Mayer akan terbentuk endapan menggumpal berwarna putih atau kuning.

2) Pada tabung II, ditambahkan 2 tetes pereaksi Dragendorff, akan terbentuk endapan berwarna coklat atau jingga kecoklatan.

3) Pada tabung III, ditambahkan 2 tetes pereaksi Bouchardat, akan terbentuk endapan berwarna coklat sampai kehitaman.

Alkaloid dianggap positif jika terjadi endapan atau paling sedikit dua atau tiga percobaan diatas (DIRJEN POM, 1995).

b. Pemeriksaan flavonoid

Sebanyak 10 gram serbuk simplisia ditimbang, dilarutkan $100 \mathrm{ml}$ air panas, dididihkan selama 5 menit dan disaring dalam keadaan panas, ke dalam $5 \mathrm{ml}$ filtrat ditambahkan 0,1 gram serbuk $\mathrm{Mg}$ dan $1 \mathrm{ml}$ HCL pekat dan $2 \mathrm{ml}$ Amil alkohol, dikocok dan dibiarkan memisah. Flavonoid positif jika terjadi warna merah, kuning,jingga, pada lapisan amil (DIRJEN POM, 1995). c. Pemeriksaan tanin

Sebanyak 0,5 gram serbuk simplisia ditimbang, ditambahkan $10 \mathrm{ml}$ air suling lalu disaring, filtratnya diencerkan dengan air sampai tidak berwarna. Larutan diambil sebanyak $2 \mathrm{ml}$ dan ditambahkan 1-2 tetes pereaksi Besi (III) Klorida dan $(\mathrm{HCl}) 1 \%$. Jika terjadi warna biru atau hijau kehitaman menunjukan adanya tannin (DIRJEN POM, 1995).

d. Pemeriksaan steroid

Sebanyak 1 gram serbuk simplisia ditimbang, dimaserasi dengan $20 \mathrm{ml} \mathrm{N}$ heksan selama 2 jam, lalu disaring. Filtrat diuapakan dalam cawan penguap. Pada sisa ditambahkan 20 tetes Asam Asetat Anhidrat dan 1 tetes Asam Sulfat pekat (pereaksi Lieberman-Burchard). Timbul warna biru atau hijau menunjukan adanya steroid(DIRJEN POM, 1995).

e. Pemeriksaan saponin

Sebanyak 0,5 gram serbuk simplisia ditimbang, dimasukkan kedalam tabung reaksi dan ditambahkan $10 \mathrm{ml}$ Air suling panas, didinginkn kemudian dikocok kuat kuat selama 10 detik. Saponin positif jika terbentuk buih atau busa yang selama tidak kurang dari 10 menit setinggi 1-10 cm, dan dengan penambahan 1 tetes larutan Asam Klorida $2 \mathrm{~N}$ buih tidak hilang (DIRJEN POM, 1995).

\section{E. Pembuatan Formula}

1. Menimbang semua bahan yang diperlukan bahan yang terdapat dalam formula dipisahkan menjadi dua kelompok yaitu fase minyak dan fase air.

2. Fase minyak yaitu asam stearate, paraffin liquidum, nipasol dipindahkan dalam cawan porselin, dipananskan di atas hot plate dengan suhu $70^{\circ} \mathrm{C}$ sampai lebur.

3. Fase air yaitu Trietanolamin, nipagin dan aquadest, dipanaskan di atas hote plate ada suhu $70^{\circ} \mathrm{C}$ sampai lebur.

4. Fase air dimasukkan secara perlahan kedalam fase minyak kemudian ditambahkan gliserin dengan pengadukan yang konsentrasi sampai diperoleh massa krim yang homogen.

5. Setelah homogen tambahkan $0,5 \mathrm{ml}$ minyak zaitun.

6. Kemudian dituang ekstrak daun Beluntas ke dalam cawan porselin yang berisi 10 gram krim, digerus perlahan-lahan sampai homogen. 


\section{F. Pengujian stabilitas formula}

1. Uji Organoleptis

Uji organoleptis dilakukan secara makroskopis dengan memeriksa bau, warna dan konsistensi sediaan. Memiliki beberapa persyaratan yaitu : memiliki warna seperti zat aktif, memiliki aroma khas zat aktif(Lina susanti, 2016).

2. Uji Homogennitas

Krim diletakkan diantara 2 kaca objek lalu diperhatikan adanya partikel kasar atau ketidak homogenan di bawah cahaya (Rosmala Dewi, 2014).

3. Uji pH

Sebaiknya $\mathrm{pH}$ disesuaikan dengan $\mathrm{pH}$ kulit, yaitu sekitar 4-7,5 karena jika $\mathrm{pH}$ terlalu besar maka dapat menyebabkan kulit menjadi bersisik, sedangkan apabila terlalu asam maka akan terjadi iritasi kulit (Helen Eliska Trianti Gurning, 2016).

4. Uji Daya Sebar

Uji Daya sebar/penghamburan dilakukan dengan objek glas dan anak timbangan. Sampel sebanyak 0,5 gram diletakkan pada objek glass kemudian sampel diberi 200 gram beban menggunakan anak timbangan, setelah itu diukur diameter penyebarannya. Daya sebar krim yang baik antara $5-7 \mathrm{~cm}$ (Gurning Trianti Eliska Helen, 2016).

5. Uji daya lekat krim

Uji ini dilakukan dengan alat tes daya melekat krim. Dua objek glass, stopwatch, anak timbangan gram dan dilakukan dengan cara melekatkan krim secukupnya di atas objek glass yang lain di atas krim tersebut kemudian ditekan dengan beban $0,5 \mathrm{~kg}$ selama 5 menit kemudian pasang beban seberat 20 gram dan dicatat waktunya hingga kedua objek tersebut terlepas. Nilai uji daya lekat yang baik untuk krim adalah 2-300 detik(Rosmala Dewi, 2014).

6. Cycling Test

Sampel krim disimpan pada suhu $2-4^{\circ} \mathrm{C}$ selama $24 \mathrm{jam}$, pada suhu kamar $\left(16-25^{\circ} \mathrm{C}\right)$ selama $24 \mathrm{jam}$, dan pada suhu panas $\left(40^{\circ} \mathrm{C}\right)$ selama 24 jam (Rosmala Dewi, 2014).

\section{HASIL DAN PEMBAHASAN}

\section{A. Hasil Penelitian}

1. Hasil Penelitian Uji Identifikasi

Tabel I. Hasil pemeriksaan identifikasi kandungan senyawa kimia ekstrak methanol daun Beluntas (Pluchea indica L.) yang berasal dari kota Benteng Kabupaten Kepulauan Selayar Provinsi Sulawesi Selatan

\begin{tabular}{|c|c|c|c|c|}
\hline \multirow{2}{*}{$\begin{array}{l}\text { Pemeriksaan } \\
\text { senyawa }\end{array}$} & \multirow{2}{*}{$\begin{array}{l}\text { Pereaksi } \\
\text { pelarut }\end{array}$} & \multicolumn{2}{|c|}{ Hasil pengamatan } & \multirow[t]{2}{*}{$\overline{\text { Ket }}$} \\
\hline & & Pengamatan & Pustaka & \\
\hline \multirow[t]{3}{*}{ Alkaloid } & Mayer & $\begin{array}{l}\text { ada endapan } \\
\text { kuning }\end{array}$ & $\begin{array}{l}\text { Endapan } \\
\text { kuning }\end{array}$ & + \\
\hline & Bouchardat & $\begin{array}{l}\text { Tidakada } \\
\text { endapan } \\
\text { coklat }\end{array}$ & $\begin{array}{l}\text { Endapan } \\
\text { coklat }\end{array}$ & - \\
\hline & Dragendoft & $\begin{array}{ll}\text { Tidak } & \text { ada } \\
\text { endapan } & \\
\text { jingga } & \end{array}$ & $\begin{array}{l}\text { Endapan } \\
\text { jingga }\end{array}$ & - \\
\hline Saponin & $\mathrm{HCl}$ Pekat & Berbusa & berbusa & + \\
\hline Steroid & $\begin{array}{l}\text { Eter } \\
\text { Liberman- } \\
\text { bouchard }\end{array}$ & Merah & Merah & + \\
\hline Tanin & $\mathrm{FeCl}_{3}$ & $\begin{array}{l}\text { Hijau } \\
\text { kehitaman }\end{array}$ & $\begin{array}{l}\text { Hijau } \\
\text { kehitaman }\end{array}$ & + \\
\hline Flavonoid & $\begin{array}{l}\text { Serbuk } \mathrm{Mg} \\
\mathrm{HCl} \text { Pekat } \\
\mathrm{C}_{5} \mathrm{H}_{11} \mathrm{OH}\end{array}$ & $\begin{array}{l}\text { Kuning dan } \\
\text { merah }\end{array}$ & $\begin{array}{l}\text { Merah, } \\
\text { kuning/ } \\
\text { jingga }\end{array}$ & + \\
\hline
\end{tabular}

2. Hasil Penelitian Uji Stabilitas Krim

a. Pemeriksaan Organoleptis

Tabel II. Pengamatan Organoleptis Sediaan Krim

\begin{tabular}{llll}
\hline Formulasi & \multicolumn{3}{c}{ Pemeriksaan Organoleptis Sediaan } \\
& \multicolumn{3}{c}{ Krim } \\
\cline { 2 - 4 } & Warna & Bau & Tekstur \\
\hline Formula 1 & Hijau & Bau khas & Semi padat \\
\hline Formula 2 & Hijau & Bau khas & Semi padat \\
\hline Formula 3 & Hijau & Bau khas & Semi padat \\
\hline
\end{tabular}

b. Homogenitas

Tabel III. Pengamatan Homogenitas SediaanKrim

\begin{tabular}{ccc}
\hline Formulasi & Susunan Homogenitas & Literatur \\
\hline Formula 1 & Homogen & Homogen \\
\hline Formula 2 & Homogen & Homogen \\
\hline Formula 3 & Homogen & Homogen \\
\hline
\end{tabular}

c. Pengukuran $\mathrm{pH}$

Tabel IV. Pengukuran pH Sediaan Krim

\begin{tabular}{lcc}
\hline Formulasi & $\mathbf{p H}$ & Literatur \\
\hline Formula 1 & 6 & $4,5-7$ \\
\hline Formula 2 & 6 & $4,5-7$ \\
\hline Formula 3 & 5 & $4,5-7$ \\
\hline
\end{tabular}

d. Uji Daya Sebar

Tabel V. PengukuranDaya Sebar Sediaan Krim

\begin{tabular}{lcc}
\hline Formulasi & $\begin{array}{c}\text { Diameter } \\
\text { Penyebaran }\end{array}$ & Literatur \\
\hline Formula 1 & $6 \mathrm{~cm}$ & $5-7 \mathrm{~cm}$ \\
\hline Formula 2 & $5,5 \mathrm{~cm}$ & $5-7 \mathrm{~cm}$ \\
\hline Formula 3 & $5 \mathrm{~cm}$ & $5-7 \mathrm{~cm}$ \\
\hline
\end{tabular}


e. Uji Daya lekat

Tabel VI. Pengukuran Daya Lekat Krim

\begin{tabular}{lll}
\hline Formulasi & Daya lekat & Literatur \\
\hline Formula 1 & 72 detik & 2-300 detik \\
\hline Formula 2 & 104 detik & 2-300 detik \\
\hline Formula 3 & 146 detik & 2-300 detik \\
\hline
\end{tabular}

f. Cycling test

Tabel VII. Pengamatan suhu

\begin{tabular}{|c|c|c|c|c|}
\hline \multirow[t]{2}{*}{ Formulasi } & \multicolumn{3}{|c|}{ Suhu } & \multirow[t]{2}{*}{ Literature } \\
\hline & $2-4^{\circ} \mathrm{C}$ & $16-25^{\circ} \mathrm{C}$ & $40^{\circ} \mathrm{C}$ & \\
\hline Formula 1 & $\begin{array}{l}\text { Baik } \\
\text { (Tidak } \\
\text { memisah) }\end{array}$ & $\begin{array}{l}\text { Baik } \\
\text { (Tidak } \\
\text { memisah) }\end{array}$ & $\begin{array}{l}\text { Baik } \\
\text { (Tidak } \\
\text { memisah) }\end{array}$ & $\begin{array}{l}\text { Tidak } \\
\text { terjadi } \\
\text { pemisahan } \\
\text { Fase }\end{array}$ \\
\hline Formula 2 & $\begin{array}{l}\text { Baik } \\
\text { (Tidak } \\
\text { memisah) }\end{array}$ & $\begin{array}{l}\text { Baik } \\
\text { (Tidak } \\
\text { memisah) }\end{array}$ & $\begin{array}{l}\text { Baik } \\
\text { (Tidak } \\
\text { memisah) }\end{array}$ & $\begin{array}{l}\text { Tidak } \\
\text { terjadi } \\
\text { pemisahan } \\
\text { Fase }\end{array}$ \\
\hline Formula 3 & $\begin{array}{l}\text { Baik } \\
\text { (Tidak } \\
\text { memisah) }\end{array}$ & $\begin{array}{l}\text { Baik } \\
\text { (Tidak } \\
\text { memisah) }\end{array}$ & $\begin{array}{l}\text { Baik } \\
\text { (Tidak } \\
\text { memisah) }\end{array}$ & $\begin{array}{l}\text { Tidak } \\
\text { terjadi } \\
\text { pemisahan } \\
\text { Fase }\end{array}$ \\
\hline
\end{tabular}

\section{B. Pembahasan}

Penelitian ini dilakukan untuk mengetahui kandungan kimia daun Beluntas (Pluchea indica L.) dari kota Benteng Kabupaten Kepulauan selayar Provinsi Sulawesi Selatan dan untuk mengetahui kestabilan sediaan apabila dibuat sediann dalam bentuk krim dengan konsentrasi asam stearate yang berbeda-beda. Perbedaan konsentrasi asam stearat dimaksudkan untuk melihat stabilitas sediaan krim.

Cara pembuatan simplisia daun Beluntas (Pluchea indica L.) pertama-tama panen daun sekitar jam 07.00-10.00 pagi kemudian dilakukan sortasi basah untuk memisahkan kotoran-kotoran atau bahan-bahan asing yang tua dengan yang muda serta bahan yang ukurannya lebih besar atau lebih kecil tahap selanjutnya pencucian dengan air mengalir kemudian perajangan (dipotong-potong kecil) selanjutnya pengeringan dengan sinar matahari kemudian dilakukan sortasi kering maka didapatkan hasil simplisa. Cara pembuatan ekstak daun Beluntas (Pluchea indica L.) adalah dengan metode maserasi dengan pelarut methanol.

Salah satu upaya dalam pencarian tumbuhan yang berkhasiat obat tersebut dapat dilakukan dengan uji kualitatif. Uji kualitatif adalah mengidentifikasi zat-zat kimia, mengenai unsurunsur atau senyawa yang terdapat dalam suatu sampel. Identifikasi kandungan senyawa kimia yaitu pemeriksaan berdasarkan reaksi kimia antara kandungan tumbuhan dengan menggunakan pereaksi. Pada penelitian ini dilakukan beberapa uji yaitu uji alkaloid, uji steroid, uji tanin, uji saponin dan uji flavonoid.
Pada uji alkaloid dengan menggunakan tiga pereaksi yaitu pereaksi mayer, dragendorf dan bouchardat, dimana hasil yang didapatkan pada pereaksi Mayer terjadi endapan kuning, pada pereaksi Bouchardat tidak terjadi endapan coklat dan pada pereaksi Dragendrof tidak terjadi endapan, Hasil penelitian yang dilakukan menunjukkan daun Bidara (Pluchea indica L.) negatifmengandung alkaloid.

Pada uji saponin memiliki karakteristik berupa buih sehingga jika ditambahkan dengan air panas dan $\mathrm{HCl}$ lalu dikocok maka akan terbentuk buih yang dapat bertahan lama. Hasil penelitian yang dilakukan menunjukkan adanya buih atau busa dimana daun Bidara (Pluchea indica L.) ini positif mengandung saponin.

Pada uji steroid yaitu ditambahkan pereaksi leberman dan bauchardat, di mana hasil yang didapatkan warna merah, daun Bidara (Pluchea indica $\mathrm{L}$.) positif mengandung steroid.

Pada uji tanin yaitu ditambahkan $\mathrm{NaCl}$ dan $\mathrm{FeCl}^{3}$ dimana hasil yang didapatkan warna hitam, daun Bidara (Pluchea indica $\quad$ L.) positif mengandung tannin.

Identifikasi terakhir yang dilakukan yaitu identifikasi flavonoid, pada identifikasi flavonoid didapatkan hasil berwarna kuning dan merah dimana daun Bidara (Pluchea indica L.) ini positif mengandung flavonoid.

Pada penelitian ini juga dilakukan penelitian sampai pada uji kestabilankrim ekstrak methanol daun Bidara (Pluchea indica L.), namun belum dilakukan penelitian mengenai kestabilansediaan pada kondisi yang dipercepat dan daya absorbsi dari sediaan.Untuk mengetahui kestabilan dari sediaan dilakukan beberapa pengujian, yang meliputi pemeriksaan organoleptis, pengujian homogenitas, pengukuran $\mathrm{pH}$, pengujian daya sebar, pengujian daya lekat, dan pengujian pada suhu (cycling test). Pengujian kestabilanterhadap sediaan krimantara lain:

1. Pemeriksaan Organoleptis. Pengujian ini dilakukan untuk melihat warna, bau dan konsistensi dari sediaan. Hasil pengamatan yang diperoleh dari kedua formula krimmemiliki warna dan aroma khas zat aktif. Sehingga kedua sediaan krim dapat dikatakan stabil dalam pengujian organoleptis.

2. Pengujian Homogenitas.Pengujian ini dilakukan untuk mengetahui apakah zat aktif dan bahan yang digunakan tercampur dengan baik (homogen) yaitu sediaan harus menunjukkan susunan yang homogen dan tidak terlihat adanya butiran kasar. Pada pengujian homogenitas formula krim menunjukkan susunan yang homogen sesuai literatur, pada formula 1 , formula 2 , dan formula 3 menunjukkan susunan yang homogen, sehingga formula 1 , formula 2 , dan formula 3 menarik 
dari segi homogenitas dan krim dapat menyebar rata pada kulit.

3. Pengukuran pH.Pengukuran $\mathrm{pH}$ dilakukan bertujuan untuk mengetahui apakah sediaan tersebut sesuai dengan $\mathrm{pH}$ kulit sehingga aman dalam penggunaan sediaan untuk menghindari terjadinya iritasi kulit bagi pemakainya, $\mathrm{pH}$ yang baik untuk kulit adalah 4,5-7. Hasil yang diperoleh yaitu formula krimpada formula 1 memiliki $\mathrm{pH} 6$, formula 2 memiliki $\mathrm{pH} 6$ dan pada formula 3 memiliki $\mathrm{pH}$ 5. Perbedaan $\mathrm{pH}$ dikarenakan semakin tinggi konsentrasi asam stearate dapat menurunkan nilai $\mathrm{pH}$ karena banyaknya gugus asam yang terkandung dalam asam stearat. Sehingga dapat dikatakan ketigasediaan krim tersebut baik untuk kulit. $\mathrm{pH}$ yang terlalu asam dapat mengiritasi kulit, sedangkan $\mathrm{pH}$ yang terlalu basa dapat membuat kulit menjadi bersisik.

4. Pengujian Daya Sebar.Pengujian ini dilakukan untuk mengetahui kelunakan massa krim sehingga dapat diketahui kemudahan pengolesan sediaan krim saat dioleskan pada kulit. Daya sebarkrim dapat menentukan adsorbsi pada tempat pemakaian, semakin baik daya sebarnya maka semakin banyak krim yang diabsorbsi.Daya sebar krim yang baik antara 5-7 $\mathrm{cm}$. Dari hasil pengukuran yang dilakukan, diporeh diameter penyebaran yang berbeda. Formulakrimpada formula 1 memiliki diameter $6 \mathrm{~cm}$, formula 2 memiliki diameter 5,5sedangkan formula3 memiliki diameter 5 $\mathrm{cm}$. Perbedaan daya sebar dikarenakan semakin tinggi konsentrasi asam stearat, semakin kecil luas area penyebaran yang dihasilkan karena adanya peningkatan viskositas. Sehingga dapat dikatakan ketiga sediaan krim tersebut memenuhi persyaratan uji daya sebar yang baik dan dapat dioleskan pada kulit.

5. Pengujian Daya lekat.Pengujia ini dilakukan untuk mengetahui kemampuan krim melekat pada tempat aplikasinya. Daya lekat basis berhubungan dengan lamanya kontak antara basis dengan kulit. Basis yang baik mampu menjamin waktu kontak efektif dengan kulit sehingga tujuan tercapai. Daya lekat krim yang baik antara 2-300 detik. Formula krimpada formula 1 memiliki waktu lekat yaitu 72 detik, formula 2 memiliki waktu lekat yaitu 104 detik dan formula 3 memiliki waktu lekat 146 detik. Perbedaan daya lekat dikarenakan semakin tinggi konsentrasi asam stearat, semakin lama waktu lekat krim yang dihasilkan karena adanya peningkatan viskositas. Sehingga dapat dikatakan ketiga sediaan krim tersebut memenuhi persyaratan uji daya lekat yang baik dan dapat dioleskan pada kulit.

6. Cycling Test. Pengamatan pada tiga suhu yang berbeda bertujuan untuk mengetahui apakah terjadi pemisahan fase pada suhu yang berbeda pada sediaan krim. Sediaan krim yang baik tidak menunjukkan adanya pemisahan fase. Pengamatan ini dilakukan pada suhu penyimpanan $2-4^{\circ} \mathrm{C}, 16-25^{\circ} \mathrm{C}$ dan $40^{\circ} \mathrm{C}$ dimana krim disimpan selama 24 jam pada setiap suhu. Sehingga dapat dikatakan ketiga sediaan krim tersebut memenuhi persyaratan uji daya lekat yang baik dan dapat dioleskan pada kulit. Ketiga krim menunjukkan hasil stabil dimana tidak terjadi pemisahan fase. Sehingga dapat dikatakan ketiga sediaan krim tersebut memenuhi persyaratan cycling tes yang baik dan dapat dioleskan pada kulit.

\section{KESIMPULAN DAN SARAN}

\section{A. Kesimpulan}

Berdasarkan penelitian yang telah dilakukan terhadap Daun Beluntas (Pluchea indica L.) dari kota Benteng Kabupaten Kepulauan Selayar Provinsi Sulawesi Selatan maka dapat disimpulkan bahwapengujian Identifikasi dengan metode kualitatif diperoleh hasil yaitu Alkaloid negatif (-), Flavanoid positif (+), Tanin positif(+), Steroid/Terpenoid positif (+), Saponin positif (+). Kemudian penelitian uji stabilitas krim, pada uji organoleptis ketiga formula memiliki warna hijau, aroma khas dari zat aktif. Pada uji homogenitas, ketiga sediaan krim menunjukkan susunan homogen yang baik. Pada pengukuran $\mathrm{pH}$, ketiga formula krim memenuhi persyaratan $\mathrm{pH}$ yaitu antara 4-7,5. Pada pengujian daya sebar, ketiga formula krim memenuhi persyaratan, yaitu antara 5-7. Pada uji daya lekat, ketiga formula krim memenuhi persyaratan, yaitu antara 2-300 detik. Pada cycling test, ketiga formula krim tidak menunjukkan pemisahan fase.Sehingga dapat dikatakansediaan krimpada formula tiga memiliki kestabilan yang paling baik.

\section{B. Saran}

Perlu dilakukan penelitian lebih lanjut mengenai uji efektifitas sediaan krim daun Beluntas (Pluchea indica L.) pada kulit dan perlu dilakukan penelitian mengenai ketahanan sediaan krim sebelum dan sesudah penyimpanan.

\section{DAFTAR PUSTAKA}

Agoes, A. (2010). Tanaman Obat Indonesia Buku1. Jakarta. Salemba Medika.

Depkes. (1989). Materia Medika Indonesia, Jilid V. Jakarta

Dewi Rosmala. 2014. Uji Stabilitas Fisik Formula Krim yang Mengandung Ekstrak Kacang Kedelai (Glycine max). Depok. Fakultas Farmasi Universitas Indonesia 
Gurning Trianti Eliska Helen. 2016. Formulasi Sediaan Losio Dari Ekstrak Kulit Buah Nanas (Ananas Comosus L. (Merr)) Sebagai Tabir Surya. Manado. Program Studi Farmasi FMIPA UNSRAT

Justicia Adisty charisma. 2017. Formulasi mouthwash minyak atsiri daun kemangi (Ocimum sanctum $L)$ dan kayu manis (Cinnamomum zeylanicum) dengan menggunakan Tween 80 sebagai surfaktan. Pontianak.Akademi yamasi Pontianak, Indonesia.

Koirewoa Adithya Yohanes, Fatimawati, Weny Indayana Wiyono. 2015. Isolasi dan Identifikasi Senyawa Flavonoid dalam Daun Beluntas (Pluchea indica L.). Manado. UNSTRAD

Lesmana Sii Ananda. 2012. Perbedaan Sifat Fisik dan Stabilitas Fisik Deodoran Ekstrak Etanol Daun Beluntas (Pluchea indica L.) Dengan Variasi Jumlah Sorbitan Monostearate Sebagai Emulsifying Agent. Yogyakarta. Universitas Sanata Dharma

Meila Okprid, Jenny Pontoan, Wahyudi Uun H, AthikamPratiwi. 2017. Formulasi Ekstrak Etanol Daun Beluntas (Pluchea indica L.) dan Uji Kestabilan Fisiknya. Jakarta. Universitas 17 Agustus 1945

Ningtyas Tectona Eka. 2012. Inhibisi Ekstrak Daun Beluntas (Pluchea indica L.) Terhadap Indeks Adhesi Streptococcus mutans Pada Neutrofil. Jamber. Universitas Jamber

Putra Bawa A.A, N.W. bogoriani, N.P Diantariani, dan Ni Luh Utari Samadewi. 2014. Ekstraksi zat Warna Alam dari Bonggol Tanaman pisang (Musa paradiasciaca L.) dengan Metode Maserasi, Refluks dan Sokhletasi. Bukit Jimbaran. Udayana

Putra Satria Winkanda. 2015. Kitab Herbal Nusantara. Yogyakarta. Ar-Ruzz Media

Saifuddin Azis. 2011. Standarisasi Bahan Obat Alam. Jakarta. Graha Ilmu

Singh M, Sharma S, Khokra LS. 2011. Kumar SR. Preparation and evaluation of herbal cosmetic cream. Pharmacologyonline

Simarenare Susanty Eva. 2014. Skrining Fitokimia Ekstrak Etanol Daun Gatal (Laportea decumana (Roxb) Wedd). Jayapura. Universitas Cendrawasih
Seidel V., 2006. Initial and bulk extraction. In: Sarker SD, Latif Z, \& Gray AI, editors. Natural Products Isolation 2nd edition. Totowa (New Jersey). Humana Press Inc

Sulistiono D.A. 2001. Identifikasi Tanin. Universitas Mataram. Fakultas MIPA

Susanti Lina, Pipid Kusmiyarsih. 2016. Formulasi Dan Uji Stabilitas Krim Ekstrak Etanolik Daun Bayam Duri (Amaranthus spinosus L.).Surakarta. Universitas Setia Budi

Wijaya Ari Risky. 2013. Formulasi Krim Ekstrak Lidah Buaya (Aloe vera) Sebagai Penyembuh Luka Bakar. Semarang. Unisversitas Negeri semarang 